\title{
Social and Travel Lockdown Impact Considering Coronavirus Disease (COVID-19) on Air Quality in Megacities of India: Present Benefits, Future Challenges and Way Forward
}

\author{
Suresh Jain*, Tanya Sharma \\ Department of Civil \& Environmental Engineering, Indian Institute of Technology Tirupati, Tirupati, Andhra Pradesh- \\ 517 506, India
}

\begin{abstract}
The coronavirus disease (COVID-19) created enormous pressure across the globe due to an increasing number of COVID-19 infected cases. All the governments' primary focus is to save humanity from this pandemic problem, and they have lockdown almost the entire nation to stop the spread of infection. This lockdown resulted in a considerable impact on the global as well as a local economy that will take a long time to perform with business as usual scenario. However, improvement in the air quality of the cities across the globe has emerged as a key benefit of this lockdown. Therefore, this study aims to assess the overall impact of social and travel lockdown in five megacities of India; Delhi, Mumbai, Chennai, Kolkata, and Bangalore. The study evaluated the spatiotemporal variations in five criteria pollutants over two time periods, i.e., March-April 2019 and March-April 2020 and $10^{\text {th }}-20^{\text {th }}$ March 2020 (before lockdown) and 25 $5^{\text {th }}$ March to $6^{\text {th }}$ April 2020 (during lockdown). The results highlighted a statistically significant decline in all the pollutants in all the megacities except for ozone. It was observed that the concentration of $\mathrm{PM}_{2.5}, \mathrm{PM}_{10}, \mathrm{NO}_{2}$ and $\mathrm{CO}$ declined by $\sim 41 \%\left(66-39 \mu \mathrm{g} \mathrm{m}^{-3}\right), \sim 52 \%\left(153-73 \mu \mathrm{g} \mathrm{m}{ }^{-3}\right)$, $\sim 51 \%\left(39-19 \mu \mathrm{g} \mathrm{m}^{-3}\right)$ and $\sim 28 \%\left(0.9-0.65 \mathrm{mg} \mathrm{m}^{-3}\right)$ during the lockdown phase in comparison to the before lockdown in Delhi, respectively. Similar decline in pollutant concentration was observed in other megacities as well. Further, the study conducted an expert survey to identify the possible challenges India might face after lockdown is over. All the experts said that reviving the economy will be a big challenge for the government, and it may result in some tradeoff while managing the air quality in the near future due to scarcity of funds, etc.
\end{abstract}

Keywords: Interpolation technique; Arc GIS; Air quality; Vulnerability; Environmental health.

\section{INTRODUCTION}

The entire world is facing a severe risk due to COVID-19 (Coronavirus disease) which is affecting almost all the countries (Buono et al., 2020). The World Health Organization (WHO, 2020) declared COVID-19 as a pandemic due to widespread global infection. As of May 13, 2020, 4,369,933 coronavirus cases have been reported globally. Out of which $2,456,508$ are currently infected (98\% with mild and $2 \%$ with serious or critical conditions) and around 1,913,425 are the closed cases out of which $85 \%$ recovered and $15 \%$ died. India is also facing a similar challenge due to the COVID-19 pandemic, which created an emergency in the entire country. India is at a critical stage in its fight against COVID-19 with

\footnotetext{
* Corresponding author.

Tel: +91-11-7180 0222; Fax: +91-11-2612 2874

E-mail address: sureshjain_in@yahoo.com;

sureshjain@iittp.ac.in
}

positive cases crossing 75,048 and death toll at 2440 until May 13, 2020 (MoHFW, 2020). The entire country was under complete lockdown from March 25 to April 14, 2020, for 21 days, which was further extended by the Government of India until May 3, 2020 followed by the third phase of lockdown till May 17, 2020 to tackle the spread of COVID-19. Social and travel restriction resulted in the shutdown of all the businesses which includes industries, transport (air, water, and surface), markets, shops, tourism, construction and demolition, hotels and restaurants, mining and quarrying, etc. except the limited essential services like groceries, milk, fruits and vegetable, medicines, etc. This situation already created a significant impact on the global as well as a local economy that will take adequate time to perform with business as usual scenarios. For e.g., India's fuel growth rate witnessed its worst hit over the last two decades, mainly due to lockdown in March 2020, which resulted in a decline in fuel consumption by nearly $60-70 \%$. However, according to Indian oil companies, consumption of liquefied petroleum gas (LPG) use has been increased by $15 \%$ due to more cooking at home. Nevertheless, globally one change that has 
been observed is the improvement in the air quality due to lockdown and travel restrictions (Bao and Zhang, 2020; Saadat et al., 2020). The decline in the levels of air pollution have been recently reported in many countries across the world like China, Brazil, Barcelona etc. A study conducted by Xu et al. (2020) reported the impact of COVID-19 on air pollution levels in three cities of central China. The results clearly indicated a decline in the levels of pollutants like $\mathrm{PM}_{2.5}, \mathrm{PM}_{10}, \mathrm{SO}_{2}, \mathrm{CO}$ and $\mathrm{NO}_{2}$ during the lockdown period. Further, Nakada and Urban (2020) also reported the reduction in $\mathrm{NO}, \mathrm{NO}_{2}$ and $\mathrm{CO}$ concentrations by $\sim 77.3 \% \sim 54.3 \%$ and $\sim 64.8 \%$, respectively, in the city of São Paulo, Brazil during the partial lockdown in February to April 2020 in comparison to the five-year average of the same months from 2015 to 2019. Similar declines in air pollution have been reported by other researchers like Tobías et al. (2020) in Barcelona; Dantas et al. (2020) in Rio de Jenario and Mahato et al. (2020) in Delhi. Still, there is a cost to that, i.e., the slowdown in the economy of the countries and effect on the mental wellbeing of the communities (European Environment Agency, 2020; Zambrano-Monserrate et al., 2020).

A similar effect has been observed in the Indian context. Before the lockdown, air quality was inferior in most Indian cities, and it affects the most vulnerable people in the community like children, the aging population, women, and the public having respiratory and cardiovascular problems (Aggarwal and Jain, 2015; Kumar et al., 2013; WHO, 2018). The Global Burden of Disease reported that around 3.4 million premature deaths were attributed to exposure to ambient air pollution (Stanaway et al., 2018). However, under the current India wise lockdown situation because of COVID-19, it is observed that air quality has drastically improved in most of the cities. Ogen (2020) and $\mathrm{Wu}$ et al. (2020) have reported that improvement in air quality lowers the severity of COVID19 outcomes. But this situation will not continue for a long time. As soon as the businesses are permitted to resume their operations as indicated by the Government of India after May 17, 2020, the air quality is likely to start deteriorating in most of the cities, and by the time winters will approach, it may create the same conditions as it was in the year 2019. Pollution is inevitable due to a growing economy and results as one of the outcomes of the developing economies for moving towards industrialization. Hence, there is a tradeoff between nature and human activities, which is essential to analyze to make informed decisions. Therefore, considering the current situation, we have analyzed the current state of air quality in most of the megacities in India and identified the potential future challenges. Also, a few policy measures have been suggested to control the air quality in most of the Indian cities in the coming future.

\section{METHODOLOGY}

The present study evaluated the impact of social and travel lockdown amid the COVID-19 breakout on the air quality in megacities of India, given its implications in the near future. Fig. 1 presents the overall methodological approach adopted to conduct the study.

\section{Site Description and Data Collection}

The study analyses the impact of social and travel lockdown on air quality of five megacities of India, i.e., Delhi,

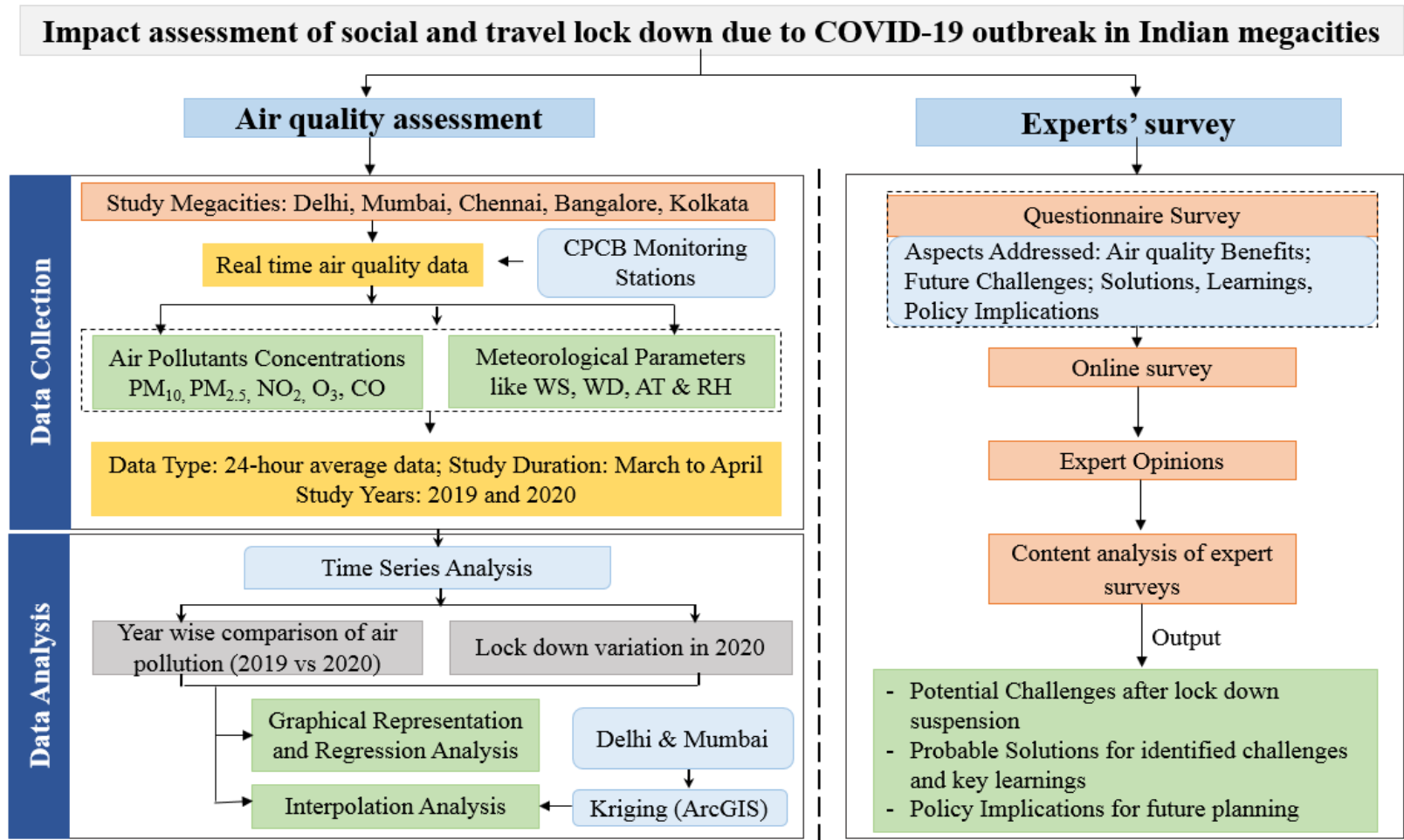

Fig. 1. Overall methodological framework used in the current study to assess the impact of lockdown in view of COVID-19 in megacities of India on air quality. 
Mumbai, Chennai, Bangalore, and Kolkata. The megacities being the economic centers of the country are susceptible to relatively higher levels of both national as well as international travel movements. Delhi and Mumbai have been regarded as epicenters for coronavirus in India are analysed separately using spatiotemporal analysis in view of correlation between air pollution exposure and COVID-19 infection. They hence are under scrutiny, and severe restrictions are presenting unusual cases for evaluation of the impact of the lockdown on air pollution. Continuous ambient air quality data monitored by various State Pollution Control Boards (SPCBs) at different monitoring stations in each city under consideration was procured through the Central Pollution Control Board, New Delhi for five criteria pollutants, i.e., particulate matter $\leq 2.5 \mu \mathrm{m}\left(\mathrm{PM}_{2.5}\right)$, particulate matter $\leq 10 \mu \mathrm{m}$ $\left(\mathrm{PM}_{10}\right)$, nitrogen dioxide $\left(\mathrm{NO}_{2}\right)$, ozone $\left(\mathrm{O}_{3}\right)$ and carbon monoxide $(\mathrm{CO})$ along with three meteorological parameters, i.e., ambient temperature (AT), wind speed (WS) and relative humidity $(\mathrm{RH})$. Air pollutants and meteorological data were procured from all the monitoring stations operational in each city, i.e., 38 in Delhi, 10 in Mumbai, 4 in Chennai, 10 in Bangalore, and 7 in Kolkata. Table 1 presents the list of all air quality monitoring stations considered in each city for data collection. Continuous 24-hour average data for the above parameters were collected for 22 days spanning over two months in 2019, i.e., from $20^{\text {th }}$ March to $10^{\text {th }}$ April 2019, while for 32 days in the year 2020, i.e., from $10^{\text {th }}$ March to $10^{\text {th }}$ April 2020.

\section{Data Analysis}

\section{Trend Analysis}

The impact of social and travel lockdown on air pollution levels of the selected megacities was inspected for two different periods, as indicated below:
1. Yearly comparison: Air quality data for the period representing lockdown months, i.e., March-April 2020 was compared with air quality data of the last year MarchApril 2019. The air quality of the cities was compared for a period of 22 days spanning over two months, i.e., from $20^{\text {th }}$ March to $10^{\text {th }}$ April for the years 2019 and 2020, respectively. The air quality data has not been analysed for Mumbai city for the same period due to the presence of enormous data gaps in the 2019 data for the pollutants considered in most of the monitoring stations of Mumbai.

2. Lockdown duration comparison was made for the time period of $10^{\text {th }}$ to $20^{\text {th }}$ March 2020 (Before lockdown period) versus $25^{\text {th }}$ March to $6^{\text {th }}$ April 2020 (During lockdown period).

A trend analysis of 24-hour daily average data for the five pollutants was considered for the above stated periods in all the cities to understand the variations in the levels of pollutant accumulation amid the lockdown period. Meteorology plays a significant role in determining air pollution levels. Therefore, time-series data were analyzed to see the effect of meteorology on air quality. A simultaneous trend analysis of meteorological parameters and air pollutants was conducted to validate the impact of lockdown on air pollution levels in the cities. Furthermore, paired t-test was used to test the significant changes in the criteria air pollutant concentrations during the lockdown period.

\section{Spatiotemporal Analysis of Air Pollution over COVID-19 Epicenters of India: Delhi and Mumbai}

One of the objectives of the present study was to map the spatiotemporal variations in the air pollution levels achieved through lockdown periods in two of the most significantly COVID-19 affected cities of India, i.e., Delhi and Mumbai. Kriging, a spatial interpolation GIS technique, was employed

Table 1. Monitoring stations considered in the selected megacities cities for data collection.

\begin{tabular}{|c|c|c|c|}
\hline S. No. & City & $\begin{array}{l}\text { Number of } \\
\text { Monitoring } \\
\text { Stations } \\
\text { Considered }\end{array}$ & List of Monitoring Stations \\
\hline 1 & Delhi & 38 & $\begin{array}{l}\text { Alipur-DPCC; Anand Vihar-DPCC; Ashok Vihar-DPCC; Aya Nagar-IMD; } \\
\text { Bawana-DPC; Burari Crossing-IMD; CRRI Mathura Road-IMD; Dr. Karni Singh } \\
\text { Shooting Range-DPCC; DTU-CPCB; Dwarka-Sector 8-DPCC; East Arjun Nagar- } \\
\text { CPCB; IGI Airport (T3)-IMD; IHBAS, Dilshad Garden-CPCB; ITO-CPCB; } \\
\text { Jahangirpuri-DPCC; Jawaharlal Nehru Stadium-DPCC; Lodhi Road-IMD; Major } \\
\text { Dhyan Chand National Stadium-DPCC; Mandir Marg-DPCC; Mundka-DPCC; } \\
\text { Najafgarh-DPCC; Narela-DPCC; Nehru Nagar-DPCC; North Campus, DU-IMD; } \\
\text { NSIT Dwarka-CPCB; Okhla Phase-2-DPCC; Patparganj-DPCC; Punjabi Bagh- } \\
\text { DPCC; Pusa-DPCC; R K Puram-DPCC; Rohini-DPCC; Shadipur-CPCB; Sirifort- } \\
\text { CPCB; Sonia Vihar-DPCC; Sri Aurobindo Marg-DPCC; Vivek Vihar-DPCC; } \\
\text { Wazirpur-DPCC }\end{array}$ \\
\hline 2 & Mumbai & 10 & $\begin{array}{l}\text { Bandra; Borivali East; Chhattrapati Shivaji Int. Airport; Colaba; Kurla; Powai; } \\
\text { Sion; Vasai, West; Vile Parle west; Worli }\end{array}$ \\
\hline 3 & Chennai & 4 & Alandur Bus Depot; Manali; Manali Village; achery Residential Area \\
\hline 4 & Bangalore & 10 & $\begin{array}{l}\text { BTM Layout; BWSSB; Bapuji Nagar; City Railway station; Hebbal; } \\
\text { Hombegowda Nagar; Jayanagar } 5^{\text {th }} \text { Block; Peenya; Sanegurava Hills; Silk Board }\end{array}$ \\
\hline 5 & Kolkata & 7 & $\begin{array}{l}\text { Ballygunge; Bidhannagar; Fort William; Jadavpur; Rabindra Bharti University; } \\
\text { Rabindra Sarobar; Victoria }\end{array}$ \\
\hline
\end{tabular}


to assess the spatial spread of air pollutants over the cities for the selected periods. Kriging is a powerful statistical technique which assumes that distance or direction between sample points reflect a spatial correlation and hence represent variation in surface (Kumar et al., 2016; van Zoest et al., 2019). It uses a weighted average technique by considering spatial correlation to predict the values for an area from the available data samples as per the following equation:

$$
Z\left(S_{o}\right)=\sum_{i=1}^{N} \lambda_{i} Z\left(S_{i}\right)
$$

where, $Z\left(s_{i}\right)=$ measured value at the ith location;

$\lambda_{i}=$ Unknown weight for measured value at ith location;

$s_{o}=$ Prediction location;

$\mathrm{N}=$ number of measured values.

The tool was employed on the air pollutant data procured through the CPCB monitoring stations to interpolate the pollutant concentrations for the entire city. It was done to identify and demonstrate the most affected, i.e., hot spots and least affected (benefited) areas within the cities.

\section{Experts' Opinion through an Online Survey}

The study conducted an expert survey to take their opinions to identify the possible challenges India might face soon after the lockdown period is over. A total of 25 responses were received from national experts, including researchers, academicians, industry experts, etc. working in the field of air quality management through an online questionnaire with an online response rate of $64 \%$. The questionnaire was comprised of both 'open-ended' as well as 'closed-ended' questions to gather the perspective of the experts regarding the current scenario as well as future implications of COVID-19 pandemic on India. The questionnaire has been presented in supplementary information (S1). The experts were provided questions to identify the possible challenges and their solutions after the lockdown period is over. The expert opinion survey was also used to identify the major learnings that can be achieved through the lockdown and how these can be used strategically for future planning and air quality management.

\section{RESULTS AND DISCUSSION}

The results of the air quality analysis have been presented in terms of yearly and daily variations observed in the pollutant concentrations due to the implementation of lockdown in the selected five megacities (Fig. 2). Spatiotemporal variations in air pollutant concentrations have also been analysed for Delhi and Mumbai. Finally, time series analysis for daily variations in the levels of air pollutants and meteorological parameters was carried out, which highlighted the impact of WS, AT, and RH on the air quality of the cities.

\section{Effects of Lockdown on-Air Quality in Megacities}

Fig. 2 shows the concentrations of all the air pollutants in Delhi, Chennai, Kolkata, Bangalore, and Mumbai before and during the lockdown as well as in 2019 and 2020. The temporal analysis of the variations in the levels of criteria air pollutants revealed that there was a significant decline in the concentration of all the pollutants except for surface ozone $\left(\mathrm{O}_{3}\right)$ in the megacities under examination. It is important to highlight that the concentrations of $\mathrm{O}_{3}$ witnessed an increase in the lockdown period in 2020, while an overall decline was observed when compared for the same duration in 2019. However, the magnitude of the decline in air pollutant concentrations is different in all the megacities. Fig. 2 clearly showed that there is no violation of the National Ambient Air Quality Standards (NAAQS for $\mathrm{PM}_{2.5}=60 \mu \mathrm{g} \mathrm{m}^{-3}, \mathrm{PM}_{10}$ $=100 \mu \mathrm{g} \mathrm{m}^{-3}, \mathrm{NO}_{2}=80 \mu \mathrm{g} \mathrm{m}^{-3}(42.54 \mathrm{ppb})$ based on a $24-$ hours average; $\mathrm{O}_{3}=100 \mu \mathrm{g} \mathrm{m}^{-3}(50.96 \mathrm{ppb})$ and $\mathrm{CO}=$ $2 \mathrm{mg} \mathrm{m}^{-3}$ (1.75 ppm) based on 8-hours average) during the lockdown period in all the megacities (the ppb and ppm values are at $25^{\circ} \mathrm{C}$ and $1013 \mathrm{mb}$ for comparison purpose). However, when compared with the WHO standards (for $\mathrm{PM}_{2.5}=25 \mu \mathrm{g} \mathrm{m}^{-3}, \mathrm{PM}_{10}=50 \mu \mathrm{g} \mathrm{m}^{-3}$ based on a 24-hours average; $\mathrm{O}_{3}=100 \mu \mathrm{g} \mathrm{m}^{-3}$ based on 8-hours average), Mumbai, Bangalore, and Chennai are within the permissible limits for $\mathrm{PM}_{2.5}$; whereas all the megacities violate WHO standards (WHO, 2018) when compared in terms of $\mathrm{PM}_{10}$ levels. Moreover, all the megacities are within the permissible limits without any violations for $\mathrm{O}_{3}$. Further, all the criteria pollutant concentrations were within the NAAQS limit before the lockdown except for $\mathrm{PM}_{2.5}$ in Delhi $\left(66 \mu \mathrm{g} \mathrm{m}^{-3}\right)$ and $\mathrm{PM}_{10}$ in Delhi, Mumbai and Kolkata, with average concentrations being $153 \mu \mathrm{g} \mathrm{m}^{-3}, 126 \mu \mathrm{g} \mathrm{m}^{-3}$ and $113 \mu \mathrm{g} \mathrm{m}^{-3}$, respectively, as presented in Figs. 2(a), 2(e) and 2(i). A similar trend was observed for lockdown period March-April 2020 when compared with air quality data of the last year March-April 2019 except for $\mathrm{PM}_{2.5}\left(89 \mu \mathrm{g} \mathrm{m}^{-3}\right)$ in Delhi and $\mathrm{PM}_{10}$ levels in Delhi, Kolkata and Bangalore, $222 \mu \mathrm{g} \mathrm{m}^{-3}$, $102 \mu \mathrm{g} \mathrm{m}^{-3}, 118 \mu \mathrm{g} \mathrm{m}^{-3}$, respectively, as presented in Figs. 2(b), 2(d) and 2(f). The WHO (2018) reported that bringing down $\mathrm{PM}_{2.5}$ levels by $25 \mu \mathrm{g} \mathrm{m}^{-3}$ would result in a reduction of $15 \%$ premature deaths (mortality). Even though impact due to exposure to air pollution will not result in instantaneous mortality, and it is more of a chronic phenomenon. Therefore, immediate benefits would be more in terms of avoided morbidity and increased in healthy days.

Fig. 3 represents the percentage change in all the criteria pollutants considered in each megacity for the two periods of assessment, i.e., before vs. during lockdown in 2020 and March-April 2019 vs March-April 2020. The results of the analysis showed that the maximum dip was observed in $\mathrm{NO}_{2}$ concentrations in all the cities, with the maximum decline of $\sim 75 \%$ being observed in Mumbai for the 'before' and 'during' lockdown duration in 2020. Dutheil et al. (2020) also reported a significant reduction in $\mathrm{NO}_{2}$ levels in China due to COVID-19 pandemic. Further, Delhi witnessed a dramatic decline in all the pollutants, which can be assumed to be historic as compared to the city' air quality since the last two decades. In Delhi, there is a significant ( $\mathrm{p}$ values vary from $0.02474-0.03 \mathrm{E}-06$ ) decline of $41 \%, 52 \%, 50 \%$, $29 \%$ in the average concentration of $\mathrm{PM}_{2.5}$ from 66 to $39 \mu \mathrm{g} \mathrm{m}^{-3}, \mathrm{PM}_{10}$ from 153 to $73 \mu \mathrm{g} \mathrm{m}^{-3}, \mathrm{NO}_{2}$ from 39 to $19 \mu \mathrm{g} \mathrm{m}^{-3}$, and CO from 0.9 to $0.65 \mathrm{mg} \mathrm{m}^{-3}$, respectively during the lockdown phase in comparison to the before 

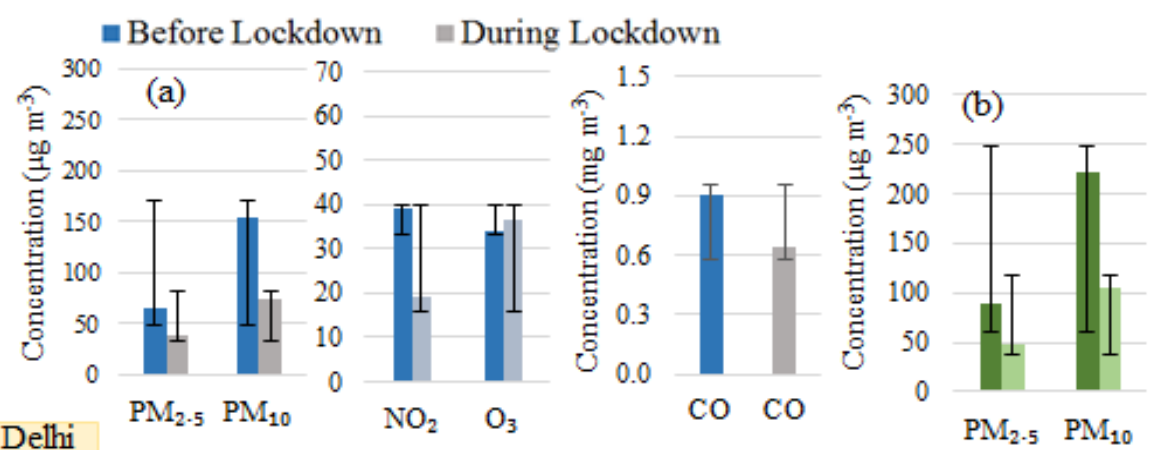

$\square 2019 \square 2020$
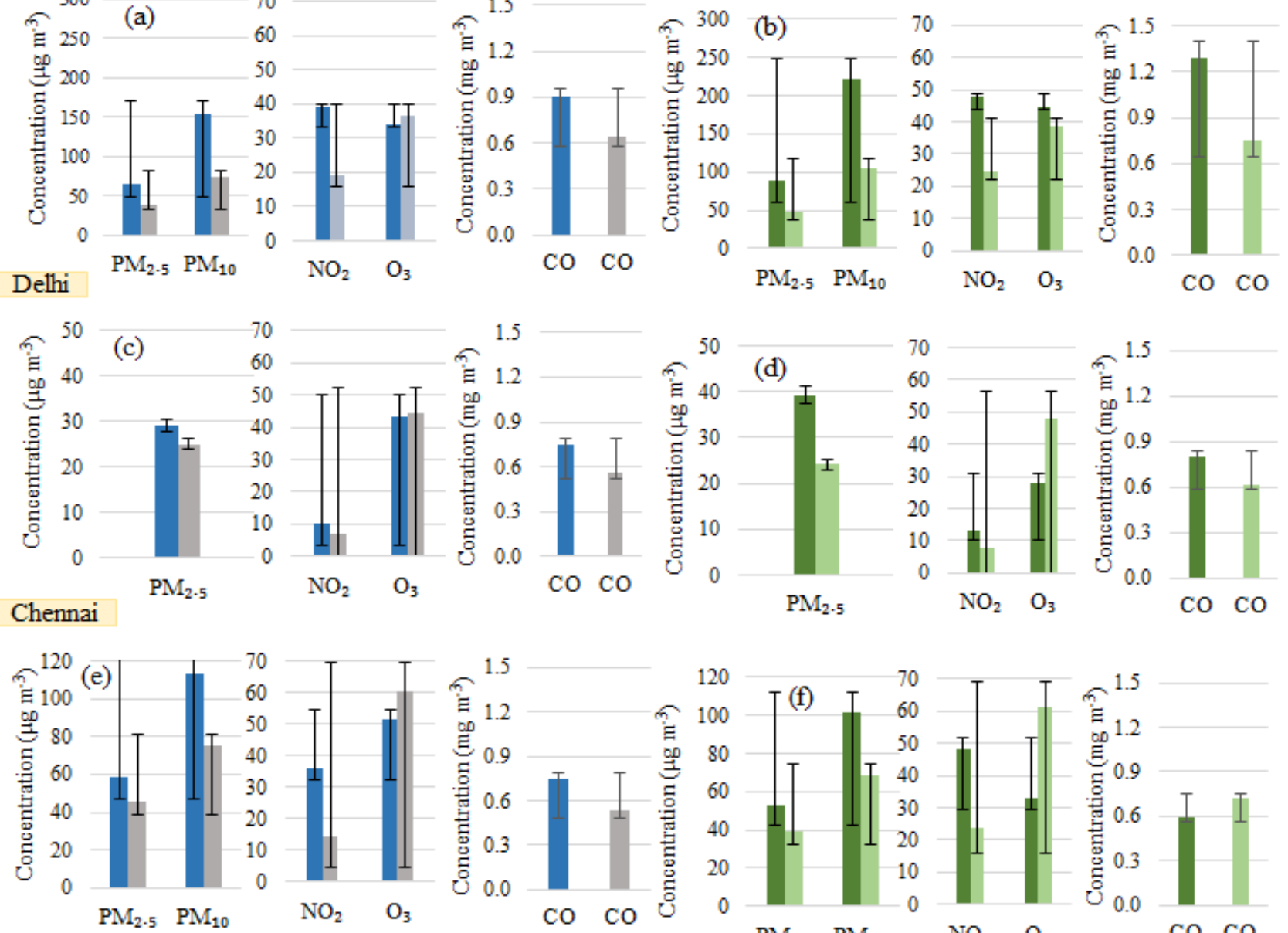

Kolkata
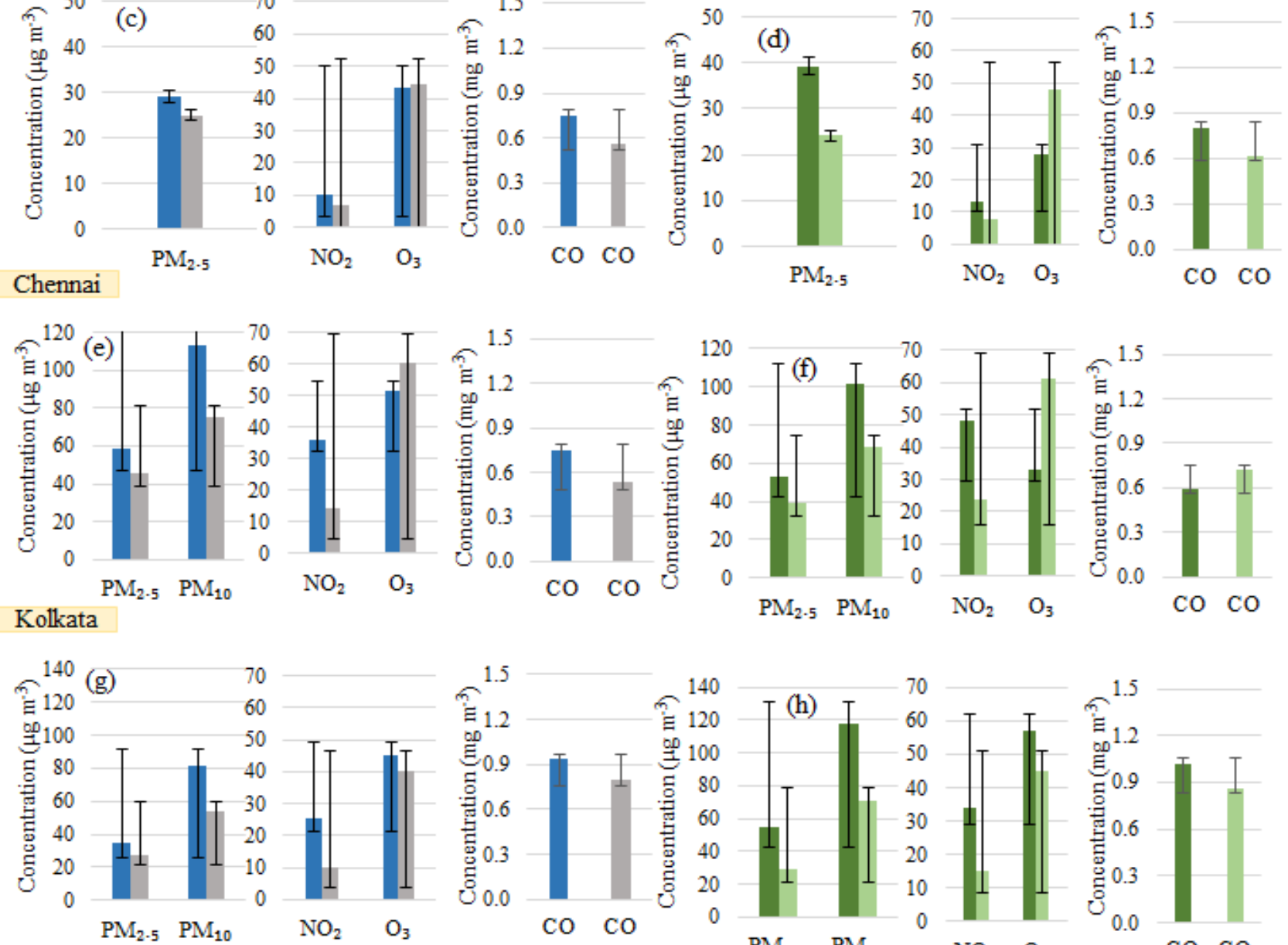

Bangalore
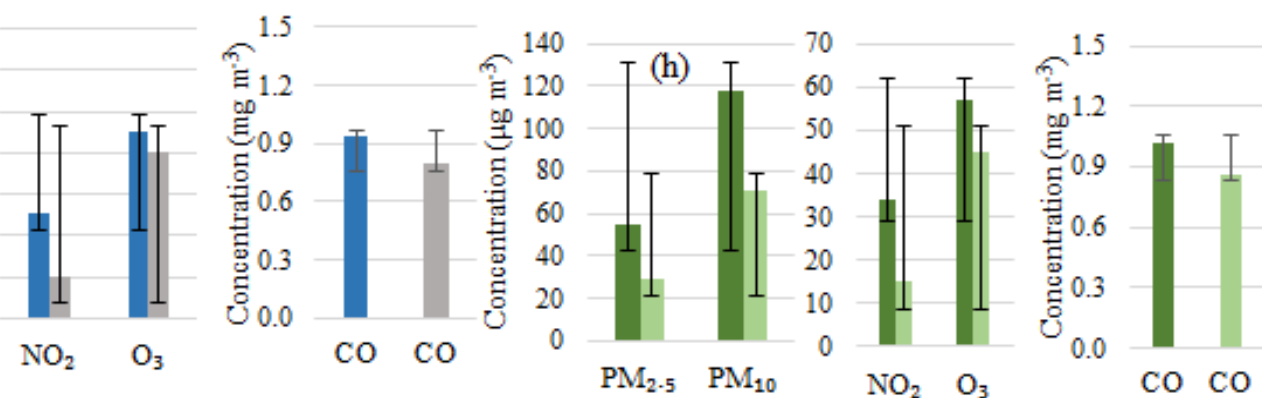

- Before Lockdown $=$ During Lockdown
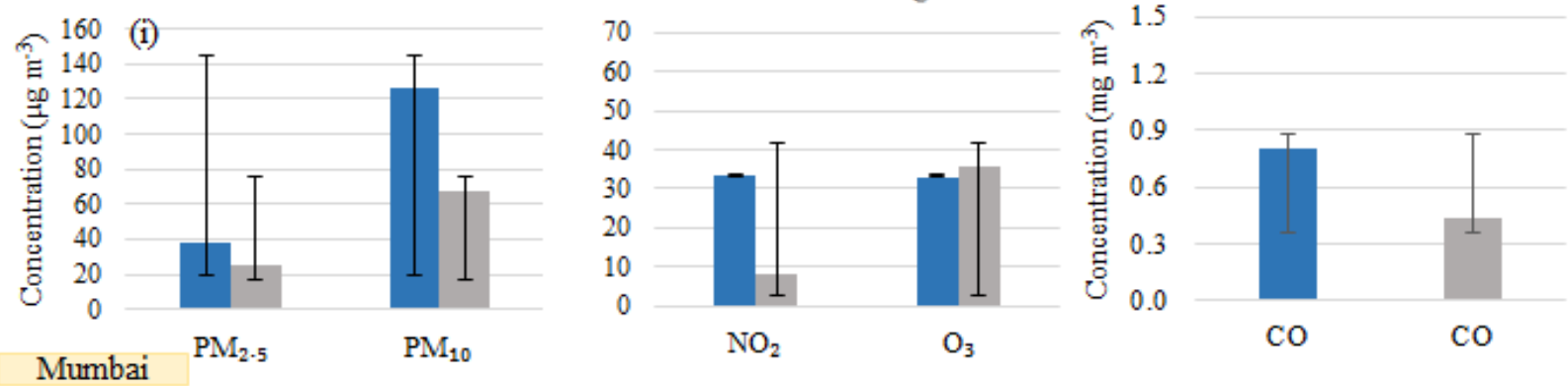

Fig. 2. Effects of lockdown on-air quality during two scenarios, i.e., effect of lockdown on air quality in compared with before lockdown and effect on air quality due to lockdown in March-April 2020 vs. last year March-April 2019. (a-b) is for Delhi; (c-d) is for Chennai; (e-f) is for Kolkata; $(\mathrm{g}-\mathrm{h})$ is for Bangalore and (i) is for Mumbai $\left(\mathrm{PM} \mathrm{NO}_{2}\right.$ and $\mathrm{O}_{3}$ are in $\mu \mathrm{g} \mathrm{m}^{-3}$ and $\mathrm{CO}$ in $\mathrm{mg} \mathrm{m}^{-3}$ ). 


\begin{tabular}{|c|c|c|c|c|c|c|c|c|c|c|}
\hline \multirow{2}{*}{ CITY } & \multicolumn{3}{|c|}{ BEFORE vs. DURING LOCKDOWN' 2020} & \multicolumn{4}{|c|}{ MARCH-APRIL 2019 vs. MARCH APRIL 2020 } \\
\cline { 2 - 11 } & $\mathrm{PM}_{2.5}$ & $\mathrm{PM}_{10}$ & $\mathrm{NO}_{2}$ & $\mathrm{CO}$ & $\mathrm{O}_{3}$ & $\mathrm{PM}_{2.5}$ & $\mathrm{PM}_{10}$ & $\mathrm{NO}_{2}$ & $\mathrm{CO}$ & $\mathrm{O}_{3}$ \\
\hline Delhi & $-41 \%$ & $-52 \%$ & $-50 \%$ & $-29 \%$ & $7 \%$ & $-45 \%$ & $-52 \%$ & $-48 \%$ & $-41 \%$ & $-14 \%$ \\
\hline Mumbai & $-33 \%$ & $-47 \%$ & $-75 \%$ & $-46 \%$ & $8 \%$ & DNA $^{*}$ & DNA* & DNA* & DNA $^{*}$ & DNA* \\
\hline Chennai & $-14 \%$ & DNA & $-32 \%$ & $-25 \%$ & $3 \%$ & $-39 \%$ & DNA & $-43 \%$ & $-23 \%$ & $73 \%$ \\
\hline Bangalore & $-22 \%$ & $-34 \%$ & $-60 \%$ & $-16 \%$ & $-11 \%$ & $-47 \%$ & $-40 \%$ & $-56 \%$ & $-15 \%$ & $-21 \%$ \\
\hline Kolkata & $-23 \%$ & $-34 \%$ & $-60 \%$ & $-29 \%$ & $17 \%$ & $-27 \%$ & $-32 \%$ & $-66 \%$ & $-16 \%$ & $87 \%$ \\
\hline
\end{tabular}

* DNA: Data Not Available.

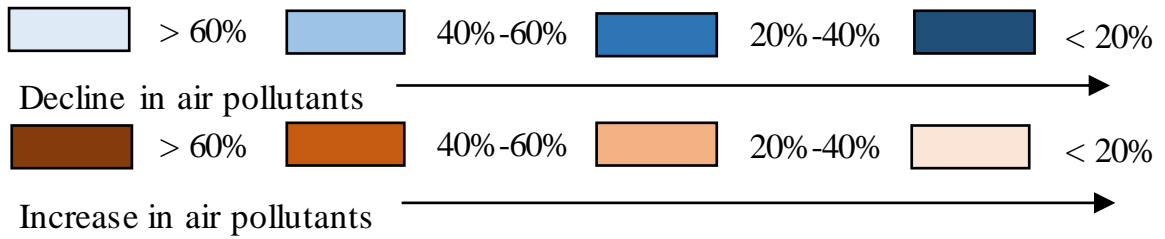

Fig. 3. Percentage decline or increase in criteria air pollutants concentrations in five megacities of India during lockdown and before lockdown period.

lockdown phase. In contrast to this, a $\sim 7 \%$ increase in $\mathrm{O}_{3}$ concentration has been observed (not significant $\mathrm{p}=0.4892$ ) in the city as shown in Fig. 2(a) due to lockdown as compared to before the lockdown period. Xu et al. (2020) also reported the similar reduction in air pollutant concentrations in three cities in Hubei Province, Wuhan, Jingmen, and Enshi in central China except an increase in $\mathrm{O}_{3}$ concentrations like Indian megacities during the lockdown period. This study compared average air pollutant concentrations for three months, i.e., January to March 2017-2019 vs. January to March 2020. In case of Wuhan city, a decline from 33\% to $45 \%$ (88.6 to $59.6 \mu \mathrm{g} \mathrm{m}^{-3}$ in January; 67.9 to $38 \mu \mathrm{g} \mathrm{m}^{-3}$ in February, and 53.1 to $34.5 \mu \mathrm{g} \mathrm{m}^{-3}$ in March) was observed in in $\mathrm{PM}_{2.5}$ concentration. A decline in $\mathrm{PM}_{10}, \mathrm{NO}_{2}$ and $\mathrm{CO}$ concentrations were observed in the range $30 \%$ to $48 \%, 30 \%$ to $61 \%$ and $7 \%$ to $23 \%$, respectively. Likewise Delhi, Wuhan also experienced an increase in $\mathrm{O}_{3}$ concentration ranging from $9 \%$ to $27 \%$ (20.4 ppb in January 2017-2019 to $22.3 \mathrm{ppb}$ in January 2020; 27.7 ppb in February 2017-2019 to $35.2 \mathrm{ppb}$ in February 2020 and 36.2 ppb in March 2017-2019 to $42.1 \mathrm{ppb}$ in March 2020), indicating the similar trends as observed in Indian megacities due to COVID-19.

The other megacities of India also witnessed a similar decline in air pollutants as reported in Delhi, as shown in Figs. 2 and 3. Chennai for instance witnessed a decline of $\sim 14 \%$ (from 30 to $26 \mu \mathrm{g} \mathrm{m}^{-3}$ ) in $\mathrm{PM}_{2.5}, \sim 30 \%\left(10-7 \mu \mathrm{g} \mathrm{m}^{-3}\right.$ ) in $\mathrm{NO}_{2}, \sim 25 \%\left(0.75-0.56 \mathrm{mg} \mathrm{m}^{-3}\right)$ in $\mathrm{CO}$ and a rise of $\sim 3 \%$ (43-44 $\mu \mathrm{g} \mathrm{m}^{-3}$ ) in $\mathrm{O}_{3}$ 'during' lockdown phase in comparison to the 'before' lockdown phase in the year 2020 as shown in Fig. 2(c). Similarly, in the 'during' lockdown phase the levels of $\mathrm{PM}_{2.5}$ declined from 58 to $45 \mu \mathrm{g} \mathrm{m}^{-3}$ in Kolkata, 35 to $27 \mu \mathrm{g} \mathrm{m}^{-3}$ in Bangalore and 37 to $25 \mu \mathrm{g} \mathrm{m}^{-3}$ in Mumbai, respectively. A similar decline in other pollutants like $\mathrm{PM}_{10}$, $\mathrm{NO}_{2}$ and $\mathrm{CO}$ amounting to $34 \%, 60 \%$ and $29 \%$ in Kolkata; $42 \%, 70 \%$ and $38 \%$ in Bangalore and $47 \%, 75 \%$ and $46 \%$ in Mumbai, respectively was observed in the 'during' lockdown phase in comparison to the 'before' lockdown phase as shown in Figs. 2(e), 2(g) and 2(i). In contrast to the trend followed by the above pollutants, the concentration of $\mathrm{O}_{3}$ witnessed an incline in all the cities except for a decline in Bangalore. The concentration of pollutant increased from 51 to $60 \mu \mathrm{g} \mathrm{m}^{-3}$ in Kolkata, 33 to $36 \mu \mathrm{g} \mathrm{m}^{-3}$ in Mumbai and 43 to $44 \mu \mathrm{g} \mathrm{m}^{-3}$ in Chennai as highlighted in Fig. 3. The contrasting trend of $\mathrm{O}_{3}$ may be due to more favorable conditions for photochemical reactions attributed to increased solar insolation and a decrease in $\mathrm{NO}_{2}$ leading to changes in the photochemical reactions determining ozone formation and destruction (Sharma et al., 2016; Dang and Liao, 2019; Xu et al., 2020). The underlying chemistry between anthropogenic emissions like $\mathrm{NO}_{x}$ in a VOC-limited environment and $\mathrm{O}_{3}$ along with the meteorological parameters govern the accumulation of surface ozone in the atmosphere (Gorai et al., 2015; Saini et al., 2017). Similar increasing trends have been observed in the levels of $\mathrm{O}_{3}$ concentrations during the lockdown period in China by $\mathrm{Xu}$ et al. (2020). A better understanding about the increasing trend of $\mathrm{O}_{3}$ concentration in Indian cities can be gathered through the underlying chemistry between $\mathrm{NO}_{\mathrm{x}}$ and $\mathrm{O}_{3}$ as represented in Eqs. (1) to (3):

$$
\begin{aligned}
& \mathrm{NO}_{2}+h v \stackrel{437 \mathrm{~nm}}{\longrightarrow} \mathrm{NO}+\mathrm{O}^{*} \\
& \mathrm{O}_{2}+\mathrm{O}^{*} \rightarrow \mathrm{O}_{3} \\
& \mathrm{O}_{3}+\mathrm{NO} \rightarrow \mathrm{NO}_{2}+\mathrm{O}_{2}
\end{aligned}
$$

As evident from the above equations, $\mathrm{NO}_{2}$ and $\mathrm{NO}$ produce contrasting impact on $\mathrm{O}_{3}$ accumulation. The $\mathrm{NO}_{2}$ promotes its formation in presence of sunlight while $\mathrm{NO}$ depletes it by formulating $\mathrm{NO}_{2}$ after the reaction. Further, the air pollution studies conducted in Indian cities showed that more than $30-50 \%$ of $\mathrm{NO}_{\mathrm{x}}$ emissions are released by 
vehicles especially diesel vehicles compared to petrol driven vehicles (Aggarwal and Jain, 2015; Jain et al., 2016). Thus, in view of the current lockdown scenario wherein 70-80\% of passenger vehicles and $60-70 \%$ of goods vehicles are off the road and other reduced combustion activities results in reduced $\mathrm{NO}_{\mathrm{x}}$ emissions in a VOC-limited environment, which could have led to an increase in $\mathrm{O}_{3}$ concentration (Kim et al., 2018; Tobías et al., 2020). It is relevant to point out that the cities considered in the present study lie in VOC limited regions of India (Sharma et al., 2016), thus an increase in the levels of $\mathrm{O}_{3}$ can be understood by the decline in $\mathrm{NO}_{\mathrm{x}}$ emissions.

A similar trend has been observed in $\mathrm{PM}_{2.5}, \mathrm{PM}_{10}, \mathrm{NO}_{2}$, $\mathrm{CO}$, and $\mathrm{O}_{3}$ concentrations in Mumbai, Chennai, Bangalore, and Kolkata between March-April 2019 versus MarchApril 2020, as shown in Figs. 2(b)-2(e) and Fig. 3. A significant ( $\mathrm{p}$ values vary from $0.001-6.22 \mathrm{E}-10$ ) decrease in concentrations of $\mathrm{PM}_{2.5}$ from 89 to $48 \mu \mathrm{g} \mathrm{m}^{-3}, \mathrm{PM}_{10}$ from 222 to $97 \mu \mathrm{g} \mathrm{m}^{-3}, \mathrm{NO}_{2}$ from 48 to $25 \mu \mathrm{g} \mathrm{m}^{-3}$, CO from 1.30 to $0.75 \mathrm{mg} \mathrm{m}^{-3}$, and $\mathrm{O}_{3}$ from 45 to $38 \mu \mathrm{g} \mathrm{m}^{-3}$ amounting to $32 \%, 34 \%, 27 \%, 27 \%$, and $11 \%$ reductions, respectively, was observed between March-April 2019 and March-April 2020 in Delhi as shown in Fig. 2 (refer to Table S1 in supplementary information for ' $p$ ' values). The concentrations of air pollutants in Bangalore declined from 55 to $29 \mu \mathrm{g} \mathrm{m}^{-3}$, 118 to $71 \mathrm{\mu g} \mathrm{m}^{-3}, 34$ to $15 \mu \mathrm{g} \mathrm{m}^{-3}, 1.01$ to $0.86 \mathrm{mg} \mathrm{m}^{-3}$ and 57 to $45 \mu \mathrm{g} \mathrm{m}^{-3}$ for $\mathrm{PM}_{2.5}, \mathrm{PM}_{10}, \mathrm{NO}_{2}, \mathrm{CO}$ and $\mathrm{O}_{3}$, respectively in March-April 2020 as compared with March-April 2019. A similar trend in reduction of air pollutant concentrations from 55 to $39 \mu \mathrm{g} \mathrm{m}^{-3}, 102$ to $68 \mu \mathrm{g} \mathrm{m}^{-3}, 48$ to $16 \mu \mathrm{g} \mathrm{m}^{-3}, 0.6$ to $0.5 \mathrm{mg} \mathrm{m}^{-3}$ in $\mathrm{PM}_{2.5}, \mathrm{PM}_{10}, \mathrm{NO}_{2}$ and $\mathrm{CO}$, respectively, was observed in Kolkata in March-April 2020 in comparison to March-April 2019.

It is important to highlight that reduction in $\mathrm{PM}_{2.5}$ levels during the lockdown period may also be attributed to reduce $\mathrm{NO}_{2}$ levels, which played an influential role in the formation of secondary PM (ARAI and TERI, 2018). In addition to transportation, the other factors that resulted in a reduction in air pollution levels are shutdown of industries, construction and demolition activities, road dust, refused burning and reduction in electricity demand from thermal power plants. The power sector reported that electricity demand has reduced by $\sim 20-30 \%$ (regional variation) when compared with a week before the lockdown due to the shutdown of all schools, colleges, theaters, malls, shopping centers, corporate and utility offices and even railway systems, etc. For e.g., all the coal power plants were shutdowns in northern states of India, i.e., Haryana, Punjab and Utter Pradesh) in a radius of around $300 \mathrm{~km}$ of Delhi, except two units at Dadri Power Plant in the state of Utter Pradesh (CREA, 2020). However, stubble burning has been observed at various places in India like Central India and Southern plains (which includes cities like Bangalore, Chennai) because farmers cannot sell their agricultural residue due to the non-availability of transport. This may be another reason for the lesser amount of reduction in air pollutant concentrations in cities in Southern India compared to Northern India.

In addition to trend analysis, a spatiotemporal analysis using kriging a spatial interpolation GIS technique was carried out for Delhi and Mumbai. The spatiotemporal analysis was restricted to these cities since Delhi and Mumbai are among the most significantly affected cities in India due to COVID-19 pandemic having 5,532 and 10,527 COVID-19 cases in, respectively. Further, Frontera et al. (2020) and Zhu et al. (2020) reported a strong linkage of COVID-19 infection with higher air pollution concentrations. Therefore, Delhi and Mumbai have been analysed separately. Figs. 4(a) and 4(b) present the spatiotemporal variations in all the pollutants before and during the lockdown period in Delhi and Mumbai, respectively. The spatiotemporal analysis would help in identifying the pollution hotspots in the cities. It has been observed that the Central and Northern part of Delhi has more pollution hotspots compared to Mumbai where pollution levels are high in the Southern region. This is attributed to the fact that most of the activities are happening in the same regions, and these are the most populous compared to the rest of the areas in both the cities. In the case of Delhi, Bawana, Jahangirpuri, Anand Vihar, Mundaka are few examples where pollution levels were high. While in Mumbai, many industries such as petroleum refineries, power plants, fertilizer factories, and industries located near peripheral areas in the Southern region of Mumbai are contributing to hotspots for high $\mathrm{NO}_{2}$ and PM levels. The yearly comparison between March-April 2019 and MarchApril 2020 highlighted that Central, Northern, Western and Eastern parts of Delhi are more polluted areas in comparison to the Southwest part of the city, as shown in Fig. 4(c). The results of the analysis revealed that the concentration levels of $\mathrm{PM}_{2.5}, \mathrm{PM}_{10}$, and $\mathrm{NO}_{2}$ witnessed the maximum decline during March-April 2020 when compared to March-April 2019. There is clear evidence that due to lockdown conditions because of COVID-19, there is a significant reduction in air pollution levels in Delhi.

\section{Meteorology and Air Quality in Megacities}

In general, very high wind speed and temperature and low relative humidity favor more dispersion of air pollutants compared to calm wind speeds or stagnant days (Sharma et al., 2020). Fig. 5 shows the time series analysis of all the criteria air pollutants $\mathrm{PM}_{2.5}, \mathrm{PM}_{10}, \mathrm{NO}_{2}, \mathrm{O}_{3}$, and $\mathrm{CO}$, along with meteorological parameters like atmospheric temperature (AT), wind speed (WS - measured around $10 \mathrm{~m}$ from the ground), and relative humidity (RH) for Delhi. The time series analysis clearly showed that about 1-2 weeks before the lockdown, i.e., AT was in the range of $22-27^{\circ} \mathrm{C}$, WS less than $0.5 \mathrm{~m} \mathrm{~s}^{-1}, \mathrm{RH}$ in the range of $58-78 \%$ which are not favorable conditions for air pollutants dispersion and hence concentrations of all the criteria pollutants was high. However, immediately after the lockdown, the temperature was $27-32^{\circ} \mathrm{C}$, WS in the range of $0.7-1.2 \mathrm{~m} \mathrm{~s}^{-1}$, RH in the range of $50-64 \%$, which are more favorable conditions compared to before lockdown for more dispersion of air pollutants in the atmosphere. Putaud et al. (2004) have reported that at $50 \% \mathrm{RH}$ led to $\mathrm{PM}_{10}$ and $\mathrm{PM}_{2.5}$, respectively, 1.09 and 1.07 times as high as gravimetric measurements at $20 \%$ relative humidity; this may be attributed to particlebound water. Further, Jayamurugan et al. (2013) also reported the statistically significant negative correlations between 


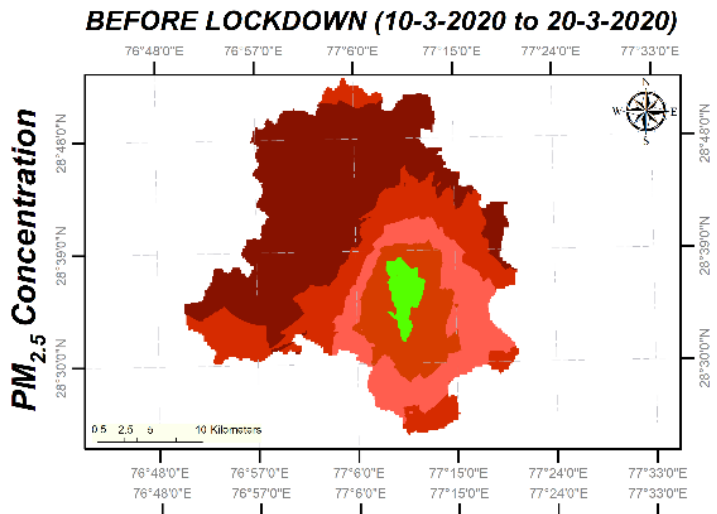

DURING LOCKDOWN (25-3-2020 to 06-4-2020)
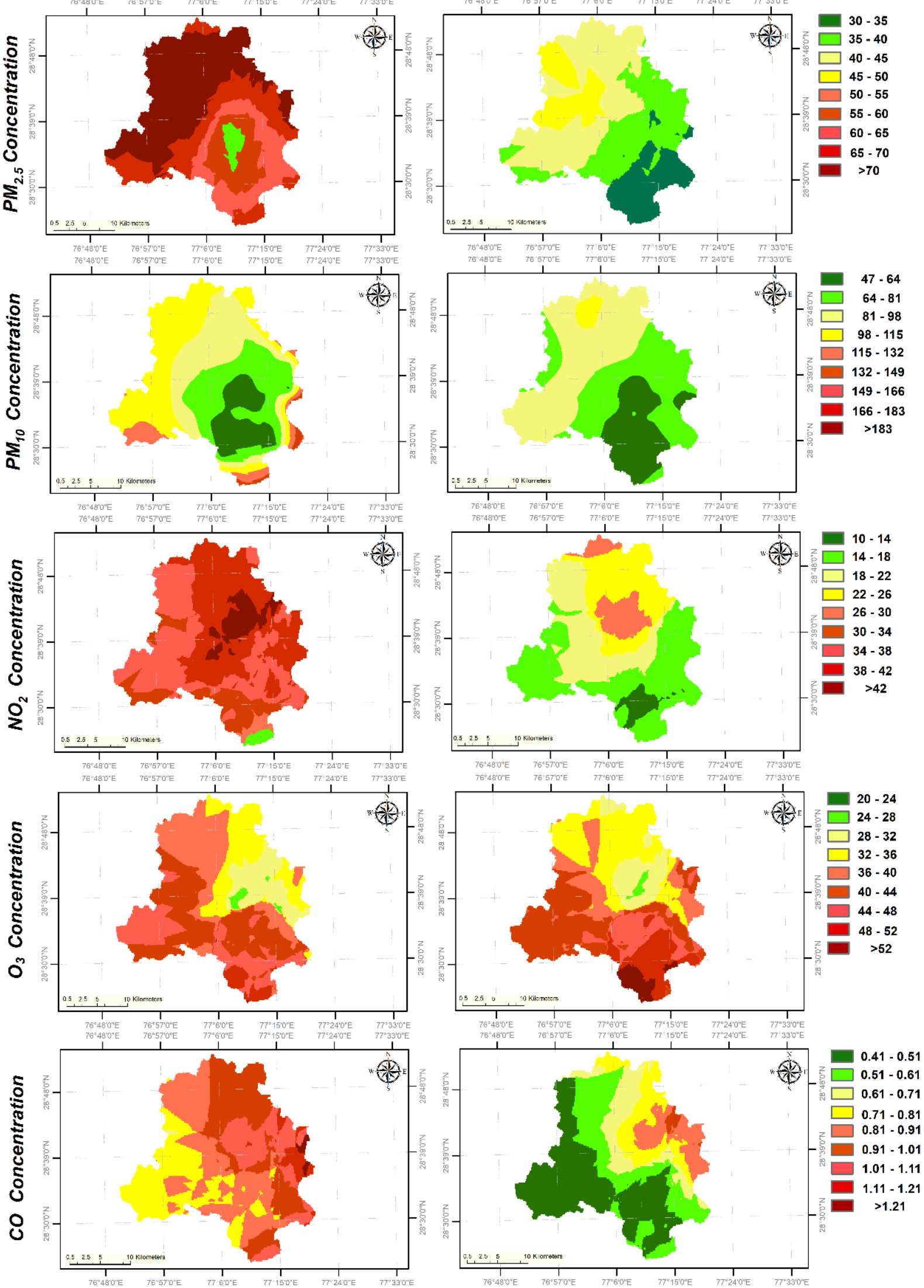

Fig. 4(a). Spatiotemporal variations in air quality due to the lockdown period compared with before lockdown period in Delhi (PM, $\mathrm{NO}_{2}$ and $\mathrm{O}_{3}$ are in $\mu \mathrm{g} \mathrm{m}^{-3}$ and $\mathrm{CO}$ in $\mathrm{mg} \mathrm{m}^{-3}$ ). 


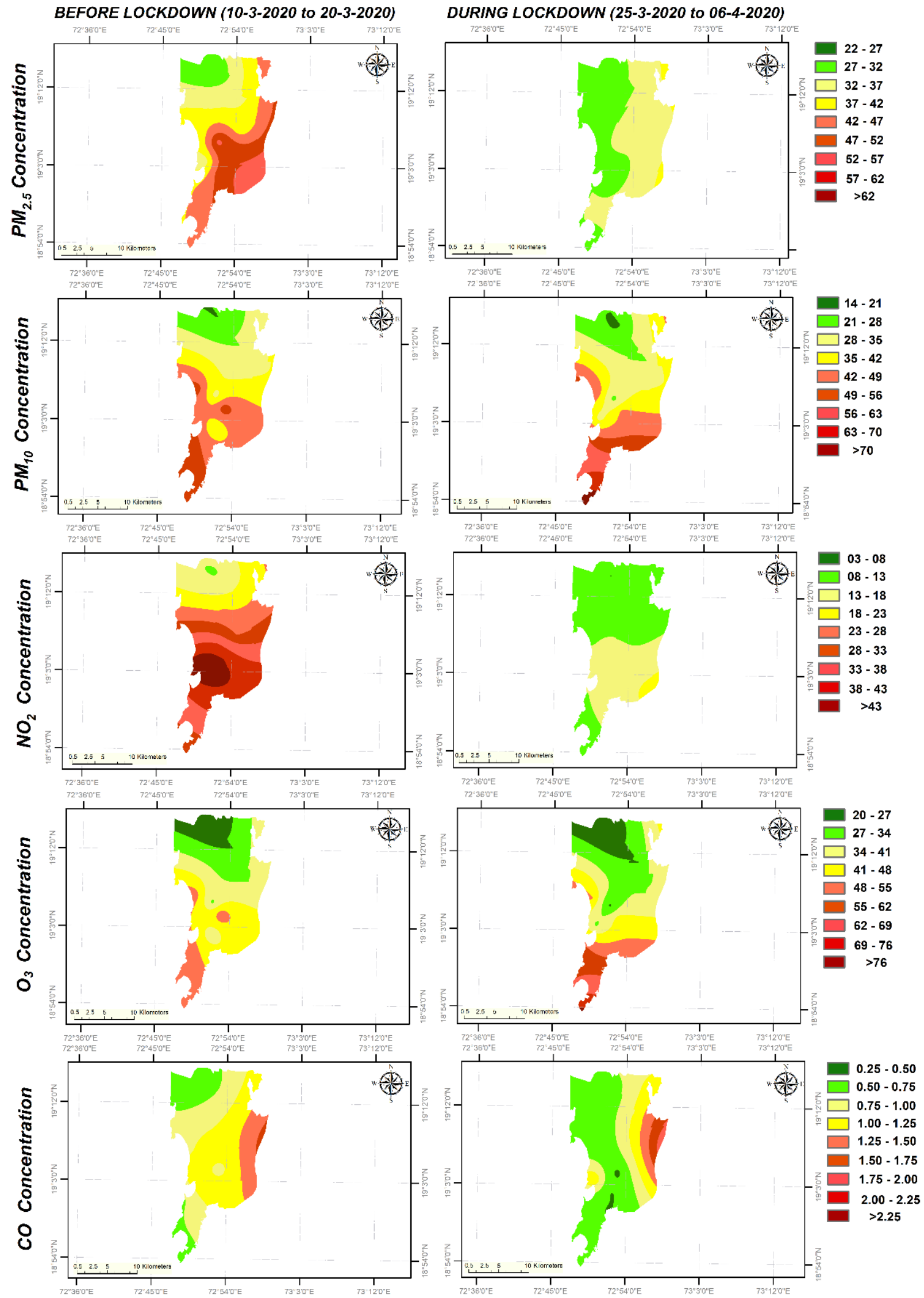

Fig. 4(b). Spatiotemporal variations in air quality due to the lockdown period compared with before lockdown period in Mumbai (PM, $\mathrm{NO}_{2}$ and $\mathrm{O}_{3}$ are in $\mu \mathrm{g} \mathrm{m}^{-3}$ and $\mathrm{CO}$ in $\mathrm{mg} \mathrm{m}^{-3}$ ). 


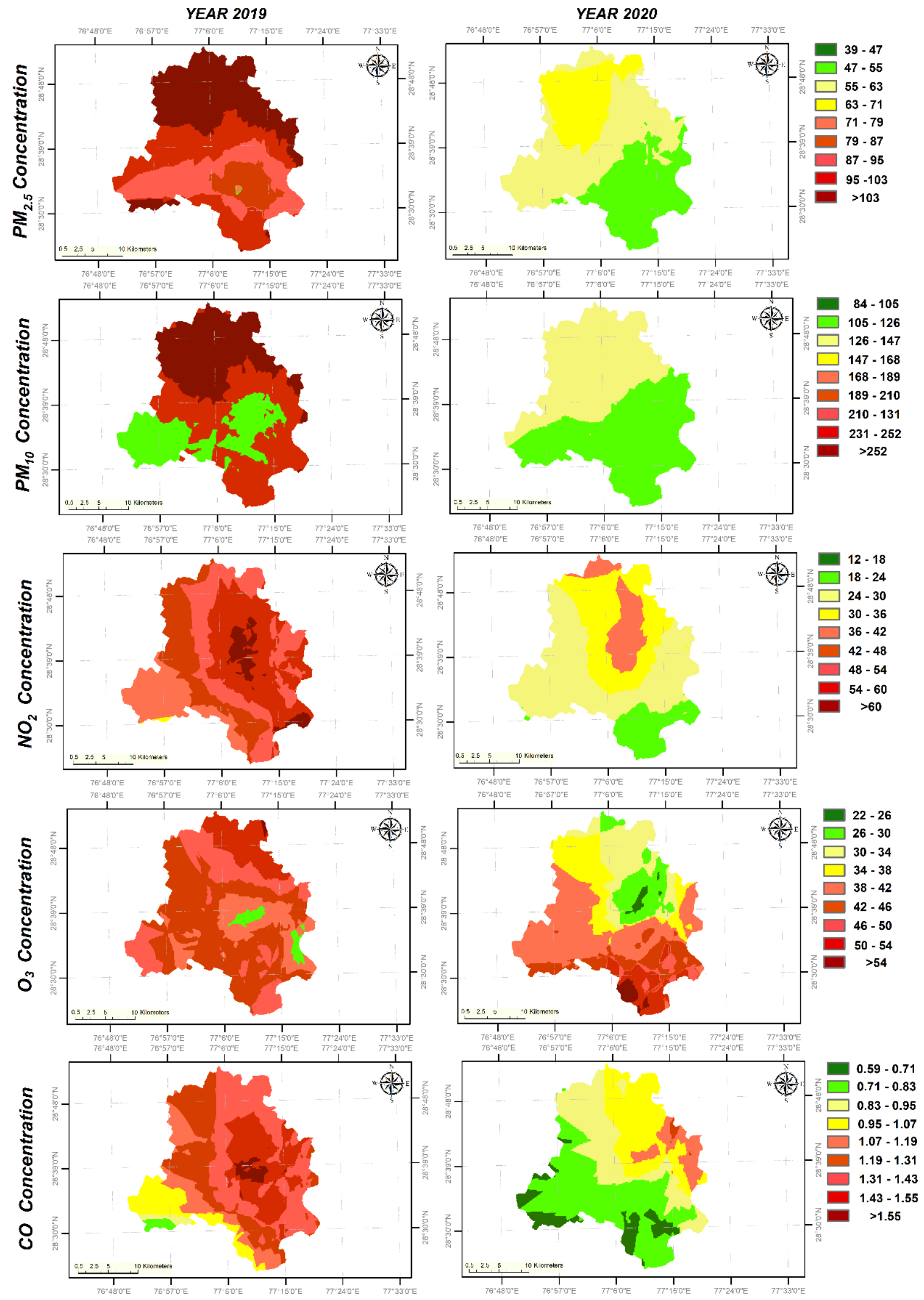

Fig. 4(c). Spatiotemporal variations in air quality in Delhi due to the lockdown in March-April 2020 vs. last year MarchApril 2019 ( $\mathrm{PM}, \mathrm{NO}_{2}$ and $\mathrm{O}_{3}$ are in $\mu \mathrm{g} \mathrm{m}^{-3}$ and $\mathrm{CO}$ in $\mathrm{mg} \mathrm{m}^{-3}$ ). 


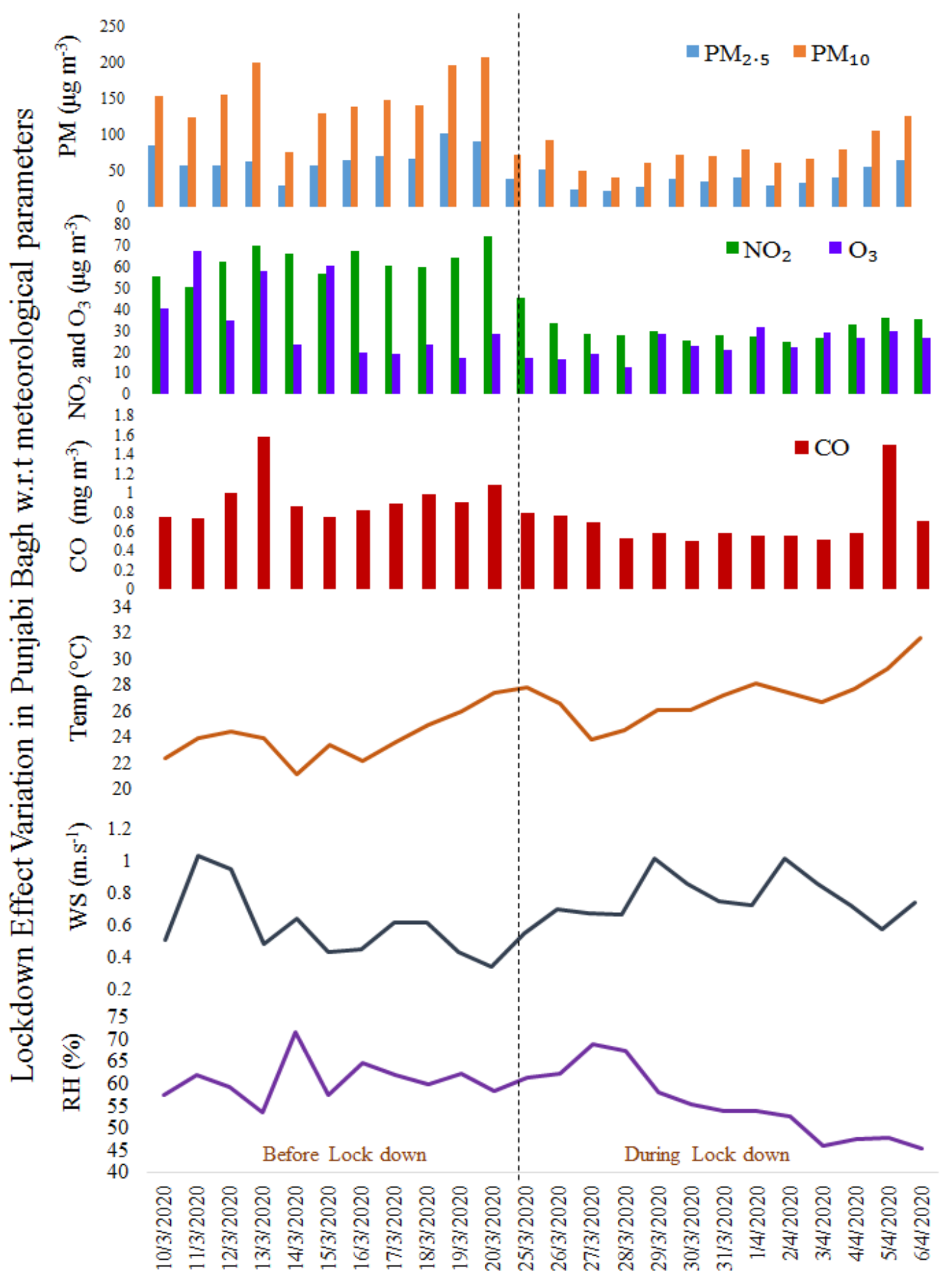

Fig. 5. Trend analysis showing the effect of lockdown period and meteorological parameters on air quality in Delhi - Punjabi Bagh monitoring station.

humidity and particulates (RSPM and SPM) and advocated the influence of humidity for subsiding particulates near the surface. Therefore, along with the lockdown, meteorological parameters also played a significant role in the reduction in air pollution levels in most of the places. Sharma et al. (2020) reported that in north India, predominant wind directions were south and southwest with average WS of around $1.5 \mathrm{~m} \mathrm{~s}^{-1}$, which further results in more dilution to air pollution levels in northern India. In contrast to the WS in northern India during the March and April months of 2020, it was lower in the southern India, i.e., $\sim 1.0 \mathrm{~m} \mathrm{~s}^{-1}$ and eastern India, i.e., $0.7 \mathrm{~m} \mathrm{~s}^{-1}$ as reported by Sharma et al. (2020). Considering the variations in the meteorological parameters in the selected megacities as per their geographical locations, the decline in air pollutant concentrations was more pronounced in Delhi and Mumbai, thus, indicating the impact of meteorology on air pollution levels amidst the lockdown period as well. Further, similar time series analysis for other megacities have also been presented in Figs. S1-S4 in S3 for more clarity. 


\section{Challenges, Learnings and Solutions: Findings from Expert Opinion Survey}

The impact of COVID-19 lockdown on the air quality of the country was unanimously accepted by 24 out of the 25 experts who responded to the questionnaire (the response rate of the online survey was $64 \%$ ). Experts mention that lockdown gave several opportunities to rethink and learn beyond our boundaries to reform the infrastructure and policy measures to reduce the overall impacts on the economy and environment together (Schwartz, 2020). Majority of the experts emphasized that a lot of learnings w.r.t environmental management, especially air pollution can be learnt from this countrywide lockdown. It was highlighted that the lockdown has helped us in understanding the best-case scenario to measure the air quality gains along with the major contributors. Nearly $70 \%$ of the experts indicated that reforms in transportation sector like avoiding unnecessary travel and adopting the concept of tele-working can yield significant benefits in terms of air pollution reduction in the businessas-usual days. Expert also highlighted that non-essential activities can be identified and controlled to gain measurable air quality benefits. It is important to highlight that transportation, industries, construction and demolition, road dust, and biomass and refused burning were considered as the most important sources which led to the reduction in air pollution levels in the country.

All the experts stated that it is crucial to adopt an integrated strategy to manage the economy and environment together to plan the future development activities in India post COVID-19. They also highlighted that there would be a decline in the funds allocated to environmental activities in order to recover the economy. In view of the above concerns, all the experts were asked to report the possible challenges that the country might face after the lockdown is over. They were also asked to suggest the possible solutions to overcome the challenges which can be used to devise the future strategies of the country. The findings of the expert responses revealed that these challenges and their possible solutions could be grouped in three areas of development, i.e., social, environmental and economic. An effort was made to consolidate and identify the most frequently highlighted challenges and their solutions. Table 2 summarizes the findings of the expert opinion gathered from the survey along with a comprehensive understanding about their perspectives. In light of the findings of the expert opinion survey, it can be concluded that the present air quality scenarios taught a lesson to all the stakeholders belongs to scientific, academic, policy-decision, and politics how to handle the future air quality scenarios and which sectors need to be controlled, how much, and when (Wang et al., 2020).

\section{CONCLUSIONS}

- The study evaluated spatiotemporal variations in five criteria pollutants in Delhi, Mumbai, Chennai, Bangalore, and Kolkata over two time periods. First, between March-April 2019 and March-April 2020 and second between $10^{\text {th }}$ to $20^{\text {th }}$ March 2020 (before the lockdown) and $25^{\text {th }}$ to $6^{\text {th }}$ April 2020 (during the lockdown). The results highlighted a statistically significant decline in all the pollutants across all the megacities except for $\mathrm{O}_{3}$.

- In Delhi, there is a significant decrease of $41 \%, 52 \%$, $50 \%$, and $29 \%$ in $\mathrm{PM}_{2.5}, \mathrm{PM}_{10}, \mathrm{NO}_{2}$ and $\mathrm{CO}$ concentrations, respectively, whereas $\sim 7 \%$ increase in $\mathrm{O}_{3}$ concentrations during the lockdown phase in comparison to before lockdown phase. A significant decrease in concentrations of $\mathrm{PM}_{2.5}$ from 89 to $48 \mu \mathrm{g} \mathrm{m}^{-3}, \mathrm{PM}_{10}$ from 222 to $97 \mu \mathrm{g}$ $\mathrm{m}^{-3}, \mathrm{NO}_{2}$ from 48 to $25 \mu \mathrm{g} \mathrm{m}^{-3}, \mathrm{CO}$ from 1.30 to 0.75 $\mathrm{mg} \mathrm{m}^{-3}$, and $\mathrm{O}_{3}$ from 45 to $38 \mu \mathrm{g} \mathrm{m}^{-3}$ amounting to $32 \%$, $34 \%, 27 \%, 27 \%$, and $11 \%$ reductions, respectively, was observed between March-April 2019 and March-April 2020 in Delhi.

- Chennai also witnessed a decline of $\sim 14 \%$ (from 30 to $26 \mu \mathrm{g} \mathrm{m}^{-3}$ ) in $\mathrm{PM}_{2.5}, \sim 30 \%$ (10 to $7 \mu \mathrm{g} \mathrm{m}^{-3}$ ) in $\mathrm{NO}_{2}$, $\sim 25 \%\left(0.75\right.$ to $\left.0.56 \mathrm{mg} \mathrm{m}^{-3}\right)$ in $\mathrm{CO}$ and a rise of $\sim 3 \%$ (43 to $44 \mu \mathrm{g} \mathrm{m}^{-3}$ ) in $\mathrm{O}_{3}$ concentrations in the 'during' lockdown phase in comparison to 'before' lockdown phase in the year 2020. A similar decline in other pollutants like $\mathrm{PM}_{10}, \mathrm{NO}_{2}$ and $\mathrm{CO}$ was observed during the lockdown phase in comparison to the before lockdown phase in other megacities as highlighted in previous sections of the manuscript.

- The concentrations of $\mathrm{PM}_{2.5}, \mathrm{PM}_{10}, \mathrm{NO}_{2}, \mathrm{CO}$, and $\mathrm{O}_{3}$ in Mumbai, Chennai, Bangalore, and Kolkata in MarchApril 2020 was estimated to be lower in comparison to the concentration levels in March-April 2019. The concentrations of air pollutants in Bangalore declined from 55 to $29 \mu_{\mathrm{g} \mathrm{m}^{-3}}$ ( 47\%), 118 to $71 \mathrm{\mu g} \mathrm{m}^{-3}(\sim 40 \%)$, 34 to $15 \mu^{g_{~ m}^{-3}}$ ( 56\%), 1.01 to $0.86 \mathrm{mg} \mathrm{m}^{-3}(\sim 15 \%)$ and 57 to $45 \mu \mathrm{g} \mathrm{m}^{-3}(\sim 21 \%)$ for $\mathrm{PM}_{2.5}, \mathrm{PM}_{10}, \mathrm{NO}_{2}, \mathrm{CO}$ and $\mathrm{O}_{3}$, respectively in March-April 2020 as compared with March-April 2019.

- A similar trend in reduction of air pollutant concentrations from 55 to $39 \mu \mathrm{g} \mathrm{m}^{-3}, 102$ to $68 \mu \mathrm{g} \mathrm{m}^{-3}, 48$ to $16 \mu \mathrm{g} \mathrm{m}^{-3}$, 0.6 to $0.5 \mathrm{mg} \mathrm{m}^{-3}$ in $\mathrm{PM}_{2.5}, \mathrm{PM}_{10}, \mathrm{NO}_{2}$, and $\mathrm{CO}$, respectively, was observed in Kolkata in March-April 2020 in comparison to March-April 2019. This decline in the concentration levels could be attributed to the complete travel lockdown and suspension of all the nonessential travel activities in all the cities. The Timeseries analysis showed meteorology also played an essential role in the dispersion of air pollutants in all the megacities.

- In addition, the expert's opinion survey highlighted that the most critical challenge for India and even other countries would be uplifting the economy by bringing back all the businesses after the lockdown period is over. Furthermore, reviving the economy is going to be the topmost priority of the government, which might forego the environmental benefits gained amidst the lockdown period.

- Experts highlighted that the COVID-19 situation gave a lot of opportunities to reform our existing infrastructure and policies to make the system more resilient and to adapt to such incidents in the future (Musselwhite et al., 2020). For examples, the government can encourage egovernance initiatives, encourage work from home policy for corporates and various other businesses, improved health infrastructure to tackle such issues, invest in 
Table 2. Summary of responses received from experts in terms of potential challenges and possible solutions to manage economy and environment after lockdown in India.

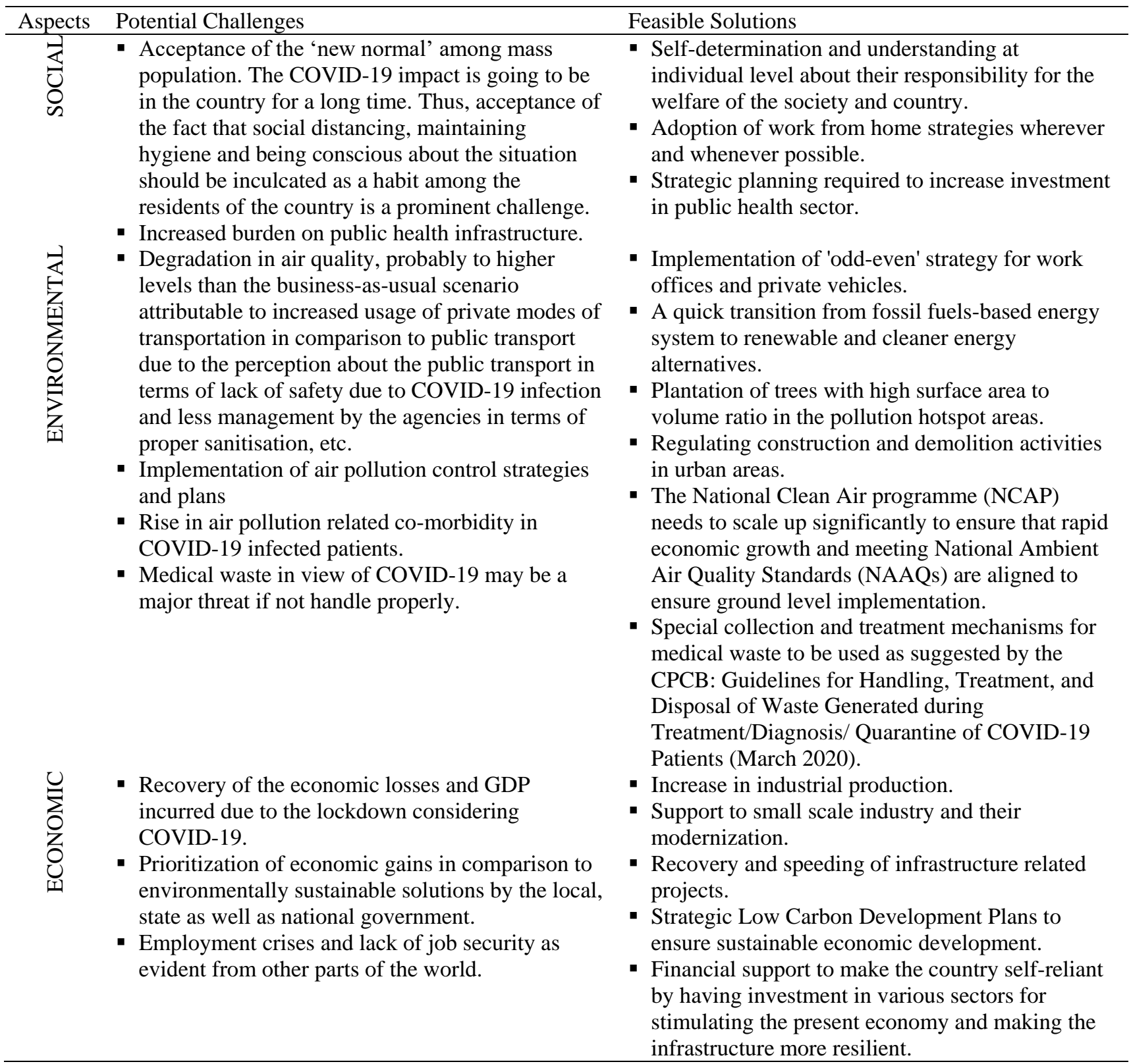

online education infrastructure to have a better adaptation to such incidence in future, investment in sustainable infrastructure, better policy to reduce the vulnerability of migrant workers under such situations, financial support micro, small and medium enterprises, etc.

- Integrated planning that caters to the environment and economy together came out as an essential suggestion from the experts, and they also highlighted to align all the policy decisions in line with the Sustainable Development Goals (SDGs).

- Most important solutions suggested by the experts to have a quick transition from fossil fuels based energy system to renewable and cleaner energy alternatives, sustainable public transport; stringent emissions control measures and proper collection and scientific treatment and disposal of municipal and medical wastes in the cities to have a clean and breathable environment in the future.

\section{DECLARATION OF COMPETING FOR INTEREST}

The authors declare that there are no financial and personal interests to influence the results and work presented in the manuscript.

\section{ACKNOWLEDGMENT}

The authors would like to thank the experts who participated in an online survey under this pandemic situation. We would like to thank the CPCB and SPCBs for ambient air quality data used in the study. We would like to 
thank our Director, IIT Tirupati for the motivation to work on COVID-19 and air quality issues and their solutions.

\section{AUTHOR STATEMENT}

Suresh Jain: Concept, Methodology, Data presentation, Analyses and writing the original manuscript.

Tanya Sharma: Methodology, Data collection, Data analysis, Writing the original manuscript.

\section{SUPPLEMENTARY MATERIAL}

Supplementary data associated with this article can be found in the online version at http://www.aaqr.org.

\section{REFERENCES}

Aggarwal, P. and Jain, S. (2015). Impact of air pollutants from surface transport sources on human health: A modeling and epidemiological approach. Environ. Int. 83: 146-157. https://doi.org/10.1016/j.envint.2015.06.010

ARAI and TERI (2018). Source Apportionment of PM 2.5 \& $P M_{10}$ of Delhi NCR for Identification of Major Sources. Report No. Department of Heavy Industry Ministry of Heavy Industries and Public Enterprises, New Delhi, ARAI/16-17/DHI-SA-NCR/Final. https://www.teriin.org /project/source-apportionment-pm25-pm10-delhi-ncr-ide ntification-major-sources.

Bao, R. and Zhang, A. (2020). Does lockdown reduce air pollution? Evidence from 44 cities in northern China. Sci. Total Environ. 731: 139052. https://doi.org/10.1016/j.sci totenv.2020.139052

Buono, M.G.D., Iannaccone, G., Camilli, M., Buono, R.D. and Aspromonte, N. (2020). The Italian outbreak of COVID19: Conditions, contributors, and concerns. Mayo Clin Proc. https://doi.org/10.1016/j.mayocp.2020.04.003

CPCB (2020). All India CAAQMS Portal. https://app.cpc bccr.com/ccr/\#/caaqm-dashboard-all/caaqm-landing

CREA (2020). Air quality improvements due to COVID 19 lock-down in India. https://energyandcleanair.org/airquality-improvements-due-to-covid-19-lock-down-in-india/

Dang, R. and Liao, H. (2019). Radiative forcing and health impact of aerosols and ozone in China as the consequence of clean air actions over 2012-2017. Geophys. Res. Lett. 46: 12511-12519. https://doi.org/10.1029/2019GL084605

Dutheil, F., Baker, J.S. and Navel, V. (2020). COVID-19 as a factor influencing air pollution? Environ. Pollut. 263: 114466. https://doi.org/10.1016/j.envpol.2020.114466

European Environment Agency (2020). Air quality and COVID-19. https://www.eea.europa.eu/themes/air/airquality-and-covid19/air-quality-and-covid19

Frontera, A., Martin, C., Vlachos, K. and Sgubin, G. (2020). Regional air pollution persistence links to COVID-19 infection zoning. J. Infect. https://doi.org/10.1016/j.jinf.2 020.03.045

Gorai, A.K., Tuluri, F. and Tchounwou, P.B. (2015). Development of PLS-path model for understanding the role of precursors on ground level ozone concentration in Gulfport, Mississippi, USA. Atmos. Pollut. Res. 6: 389-
397. https://doi.org/10.5094/APR.2015.043

Jain, S., Aggarwal, P., Sharma, P. and Kumar, P. (2016). Vehicular exhaust emissions under current and alternative future policy measures for megacity Delhi, India. $J$. Transp. Health 3: 404-412. https://doi.org/10.1016/j.jth.2 016.06.005

Jayamurugan, R., Kumaravel, B., Palanivelraja, S. and Chockalingam, M.P. (2013). Influence of Temperature, Relative Humidity and Seasonal Variability on Ambient Air Quality in a Coastal Urban Area. Int. J. Atmos. Sci. 2013: 264046. https://doi.org/10.1155/2013/264046

Kim, S., Jeong, D., Sanchez, D., Wang, M., Seco, R., Blake, D., Meinardi, S., Barletta, B., Hughes, S., Jung, J., Kim, D., Lee, G., Lee, M., Ahn, J., Lee, S.D., Cho, G., Sung, M.Y., Lee, Y.H. and Park, R. (2018). The controlling factors of photochemical ozone production in Seoul, south Korea. Aerosol Air Qual. Res. 18: 2253-2261. https://doi.org/10.4209/aaqr.2017.11.0452

Kumar, A., Gupta, I., Brandt, J., Kumar, R., Dikshit, A.K. and Patil, R.S. (2016). Air quality mapping using GIS and economic evaluation of health impact for Mumbai city, India. J. Air Waste Manage. Assoc. 66: 470-481. https://doi.org/10.1080/10962247.2016.1143887

Kumar, P., Jain, S., Gurjar, B.R., Sharma, P., Khare, M., Morawska, L. and Britter, R. (2013). New Directions: Can a "blue sky" return to Indian megacities? Atmos. Environ. 71: 198-201. https://doi.org/10.1016/j.atmosenv.2013.01.055

Mahato, S., Pal, S. and Ghosh, K.G. (2020). Effect of lockdown amid COVID-19 pandemic on air quality of the megacity Delhi, India. Sci. Total Environ. 730: 139086. https://doi.org/10.1016/j.scitotenv.2020.139086

MoHFW (2020). COVID-19 INDIA. https://www.mohfw.g ov.in/

Musselwhite, C., Avineri, E. and Susilo, Y. (2020). Editorial JTH 16 -The Coronavirus Disease COVID-19 and implications for transport and health. J. Transp. Heal. 16: 100853. https://doi.org/10.1016/j.jth.2020.100853

Nakada, L.Y.K. and Urban, R.C. (2020). COVID-19 pandemic: Impacts on the air quality during the partial lockdown in São Paulo state, Brazil. Sci. Total Environ. 730: 139087. https://doi.org/10.1016/j.scitotenv.2020.139087

Ogen, Y. (2020). Assessing nitrogen dioxide $\left(\mathrm{NO}_{2}\right)$ levels as a contributing factor to coronavirus (COVID-19) fatality. Sci. Total Environ. 726: 138605. https://doi.org/10.1016 /j.scitotenv.2020.138605

Putaud, J.P., Raes, F., Van Dingenen, R., Brüggemann, E., Facchini, M.C., Decesari, S., Fuzzi, S., Gehrig, R., Hüglin, C., Laj, P., Lorbeer, G., Maenhaut, W., Mihalopoulos, N., Müller, K., Querol, X., Rodriguez, S., Schneider, J., Spindler, G., Brink, H. ten, Tørseth, K. and Wiedensohler, A. (2004). (2004). A European aerosol phenomenology-2: chemical characteristics of particulate matter at kerbside, urban, rural and background sites in Europe. Atmos. Environ. 38: 2579-2595. https://doi.org/10.1016/j.atmos env.2004.01.041

Saadat, S., Rawtani, D. and Hussain, C.M. (2020). Environmental perspective of COVID-19. Sci. Total Environ. 728: 138870. https://doi.org/10.1016/j.scitotenv. 2020.138870 
Saini, R., Taneja, A. and Singh, P. (2017). Surface ozone scenario and air quality in the north-central part of India. Int. J. Environ. Sci. 59: 72-79. https://doi.org/10.1016/j.j es.2017.02.008

Schwartz, A.A. (2020). Climate change, Covid-19, preparedness, and consciousness. EXPLORE 16: 141144. https://doi.org/10.1016/j.explore.2020.02.022

Sharma, S., Chatani, S., Mahtta, R., Goel, A. and Kumar, A. (2016). Sensitivity analysis of ground level ozone in India using WRF-CMAQ models. Atmos. Environ. 131: 29-40. https://doi.org/10.1016/j.atmosenv.2016.01.036

Sharma, S., Zhang, M., Anshika, Gao, J., Zhang, H. and Kota, S.H. (2020). Effect of restricted emissions during COVID-19 on air quality in India. Sci. Total Environ. 728 : 138878. https://doi.org/10.1016/j.scitotenv.2020.138878

Stanaway, J.D., Afshin, A., Gakidou, E., Lim, S.S., Abate, D., Abate, K.H., Abbafati, C., Abbasi, N., Abbastabar, H., Abd-Allah, F., Abdela, J., Abdelalim, A., Abdollahpour, I., Abdulkader, R.S., Abebe, M., Abebe, Z., Abera, S.F., Abil, O.Z., Abraha, H.N., ... Murray, C.J.L. (2018). Global, regional, and national comparative risk assessment of 84 behavioural, environmental and occupational, and metabolic risks or clusters of risks for 195 countries and territories, 1990-2017: A systematic analysis for the Global Burden of Disease Study 2017. Lancet 392: 1923 1994. https://doi.org/10.1016/S0140-6736(18)32225-6

Tobías, A., Carnerero, C., Reche, C., Massagué, J., Via, M., Minguillón, M.C., Alastuey, A. and Querol, X. (2020). Changes in air quality during the lockdown in Barcelona (Spain) one month into the SARS-CoV-2 epidemic. Sci. Total Environ. 726: 138540. https://doi.org/10.1016/j.sci totenv.2020.138540

van Zoest, V., Osei, F.B., Hoek, G. and Stein, A. (2019). Spatio-temporal regression kriging for modelling urban $\mathrm{NO}_{2}$ concentrations. Int. J. Geog. Inf. Sci. 34: 851-865. https://doi.org/10.1080/13658816.2019.1667501

Wang, P., Chen, K., Zhu, S., Wang, P. and Zhang, H. (2020). Severe air pollution events not avoided by reduced anthropogenic activities during COVID-19 outbreak. Resour. Conserv. Recycl. 158: 104814. https://doi.org/10. 1016/j.resconrec.2020.104814

WHO (2018, May 2). Ambient air quality and health. ht tps://www.who.int/en/news-room/fact-sheets/detail/ambi ent-(outdoor)-air-quality-and-health

WHO (2020). Coronavirus disease (COVID-19) pandemic. https://www.who.int/emergencies/diseases/novel-corona virus-2019

Wu, X., Nethery, R.C., Sabath, B.M., Braun, D. and Dominici, F. (2020). Exposure to air pollution and COVID-19 mortality in the United States. medRxiv 2020.04.05.20054502. https://doi.org/10.1101/2020.04.05.20054502

Xu, K., Cui, K., Young, L.H., Hsieh, Y.K., Wang, Y.F., Zhang, J. and Wan, S. (2020). Impact of the COVID-19 event on air quality in central China. Aerosol Air Qual. Res. 20: 915-929. https://doi.org/10.4209/aaqr.2020.04.0150

Zambrano-Monserrate, M.A., Ruano, M.A. and SanchezAlcalde, L. (2020). Indirect effects of COVID-19 on the environment. Sci. Total Environ. 728: 138813. https://doi.org/10.1016/j.scitotenv.2020.138813

Zhu, Y., Xie, J., Huang, F. and Cao, L. (2020). Association between short-term exposure to air pollution and COVID19 infection: Evidence from China. Sci. Total Environ. 727: 138704. https://doi.org/10.1016/j.scitotenv.2020.13 8704

Received for review, April 25, 2020 Revised, May 13, 2020 Accepted, May 15, 2020 